\title{
Iowa's Industrial
}

\section{Roots: Some Social}

\section{and Political}

Problems

Keach Johnson

The American people were coming to Realize at THE turn of the century that the implications of the emerging industrial order were social and political as well as economic. They began to see that they must change their traditional patterns of social and political behavior if they were to cope with the pressures and problems of modern industrialism. The rapid growth of relatively new social classes, such as the whitecollar workers and the factory workers, intensified class consciousness, social tension, and political conflict. The nationalization and even internationalization of markets, the shift from individual to corporate enterprise, and growing public awareness of the social cost of industrialization led businessmen, farmers, laborers, and professional people to organize in order to protect their economic interests and to remedy the evils of industrial society. To achieve their goals, these groups frequently demanded public reform of economic, social, and political injustices. The effect of these demands was to expand the role of government at all levels of the federal system.

The impact of industrialization was not as pronounced in 
Iowa as it was in the leading industrial states, but it produced similar problems and responses. In Iowa as elsewhere, industrialization generated important changes in the distribution and social classification of people. Iowa's population, whose rate of growth had declined as the state became settled, fell slightly between 1900 and 1910 , from $2,231,853$ to 2,224,771, a loss of 7,082 people. This was because the rural population fell more rapidly than the urban population rose. The number of Iowans living in cities and towns of 2,500 or more inhabitants climbed from 572,386 in 1900 to 680,054 in 1910, an increase of 107,668 . Those living on farms or in communities with less than 2,500 people dropped from 1,659,467 in 1900 to $1,544,717$ in 1910 , a decrease of $114,750 .^{1}$

The movement of Iowans from the country to the city raised the urban proportion of the state's population from twenty-six percent in 1900 to thirty-one percent in 1910. Like Americans generally, most Iowans leaving the country for the city moved to the larger cities. The number of Iowans living in cities of 25,000 or more inhabitants grew from 253,537 in 1900 to 330,091 in 1910 , an increase of 76,554 or thirty percent. The number of those living in cities and towns with 2,500 to 25,000 people climbed from 313,730 in 1900 to 349,963 in 1910 , an increase of 36,233 or twelve percent. ${ }^{2}$

Industrialization further complicated Iowa's social structure by adding to the growing number of salaried employees and by creating a self-conscious class of factory workers. Of the various groups engaged in manufacturing-individual proprietors, members of firms, salaried employees, and wageearners-the latter were the most numerous by far, but the salaried employees were growing faster than any other segment of the manufacturing population. The average number of wage-earners rose from 44,420 in 1899 to 61,635 in 1909, an increase of 17,215 , or thirty-nine percent. Far outstripping that substantial increase was the 121 percent gain in the num-

${ }^{1}$ Thirteenth Census of the United States, 1910: Abstract of the Census with Supplement for Iowa (Washington, 1913), 568, 570; Census of Iowa, 1905 (Des Moines, 1905), xvii-xxv; John E. Brindley, A Study of Iowa Population as Related to Industrial Conditions, Bulletin No. 27, Engineering Experiment Station (Ames, 1912), ch. I.

${ }^{2}$ Abstraact of the Thirteenth Census with Supplement for Iowa, 570; Census of Iowa, 1905, Lxvii-Lxx. 
ber of salaried employees-officers of corporations, superintendents, managers, and clerks-which rose from 5,159 to 11,402 between 1899 and 1909. In 1909, the salaried employees included 1,424 officers of corporations, 2,067 managers and superintendents, and 7,911 clerks. ${ }^{3}$

The great majority of the Iowans engaged in manufacturing lived and worked in the state's larger cities, which mainly explains why these cities grew more rapidly than the smaller ones. Of the 78,360 Iowans engaged in manufacturing in $1909,54,936$ ( 70 percent) were located in the seventeen cities of the state with 10,000 or more inhabitants. They comprised 1,650 proprietors (individuals and members of firms), 2,169 corporate officers, superintendents, and managers, 6,272 clerks, and 44,845 wage-earners. ${ }^{4}$

The changes wrought by industrialization in the distribution and social grouping of Iowans introduced new problems and tensions into the state's political and social life. Industrialism gave rise to two of Iowa's most persistent modern problems: the mutual distrust and rivalry of urban and rural communities, and the struggle between capital and labor.

The roots of the former conflict are to be found in the clash of industrial-urban interests and needs with prevailing agricultural-rural habits of thought and action. Manufacturing was still the junior partner in Iowa's economy at the turn of the century. Most Iowans had not yet awakened to the state's industrial possibilities. Many Iowa manufacturers believed that the persistence of the popular belief that Iowa was essentially an agricultural state was the greatest obstacle to the state's industrial growth. The manufacturers complained that they were unable to capture their fair share of the state's markets because many Iowans did not buy articles manufactured in the state; that Iowa investors, especially the bankers, were more willing to lend money on farms than on factories, forcing the state's manufacturers to pay higher interest rates than their eastern competitors; and that the General Assembly

${ }^{3}$ Abstract of the Thirteenth Census with Supplement for Iowa, 681-682, 683, 686-687. The United States Census Office did not establish a separate category for salaried employees in the manufacturing industries until 1890 . Census reports prior to 1890 included salaried employees with wage-earners. Twelfth Census of the United States, 1900 (Washington, 1902), VII, Lxi.

'Abstract of the Thirteenth Census with Supplement for Iowa, 700-701, 708-709. 
The Annals of Iowa

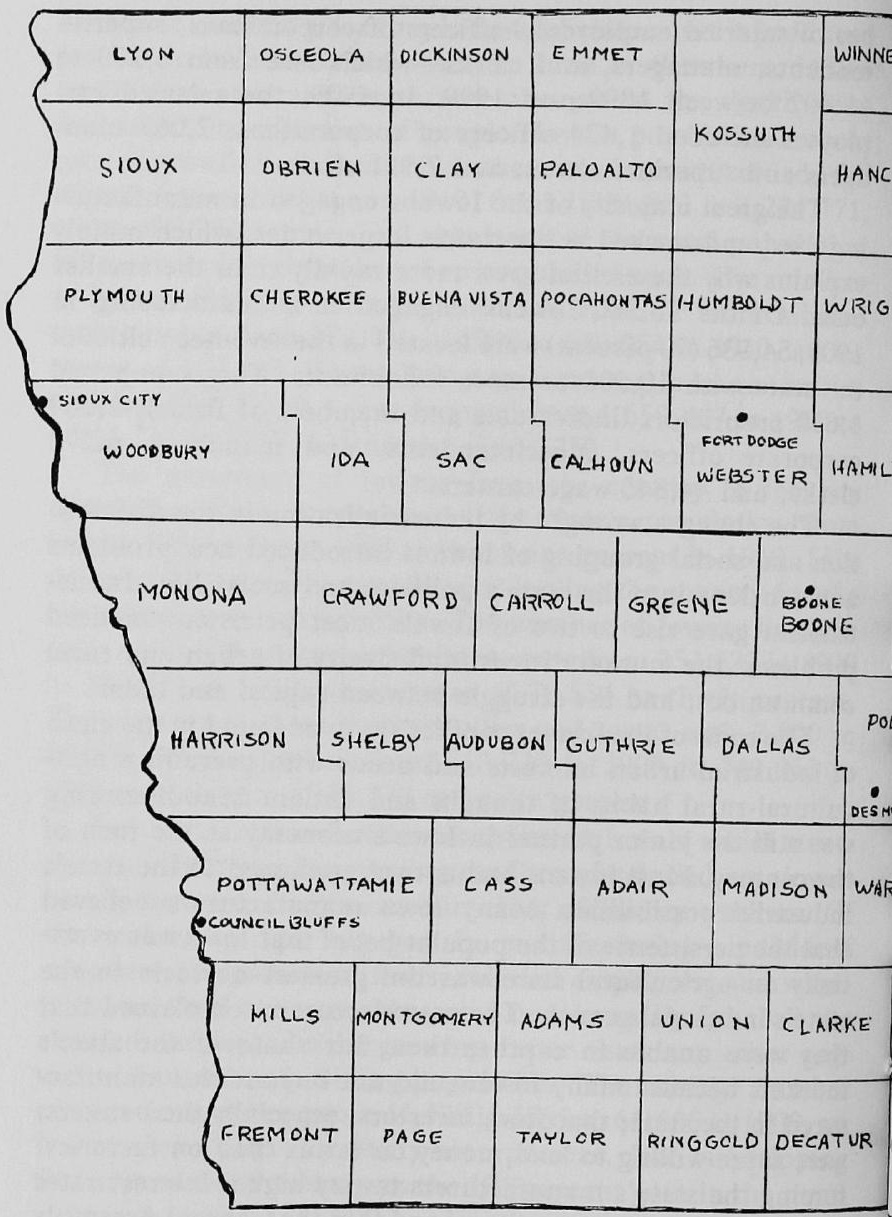


discriminated in favor of agriculture at the expense of manufacturing. ${ }^{5}$

Iowa manufacturers complained particularly of the state's neglect of industrial education. The lack of an industrial population, they said, was one of their greatest problems. Pointing out that artisans and mechanics did not come to Iowa to seek employment, the manufacturers argued that the state's shortage of skilled laborers could be overcome only by instituting an efficient system of industrial education in the secondary schools. They noted that the state was pushing the development of a statewide system of agricultural education in the public schools. The State Board of Education had recently established a department of Agricultural Education at Iowa State College to work with other departments in the college's Division of Agriculture and with the public schools in promoting agricultural education. Urging the adoption of a similar system of industrial education, manufacturers and engineers called for the creation of a Division of Engineering Extension at Iowa State College. An arm of the college, they hoped, would take the lead in setting up a statewide system of public instruction in the industrial and mechanic arts. ${ }^{6}$

The General Assembly was more responsive to the cities' political problems than to their industrial needs, perhaps because the former were more obvious and more pressing. In Iowa as in other states, the cities were forced to seek state legislation in dealing with their political and social problems. This process began in Iowa in 1904 when civic leaders of Des Moines, the state capital, undertook to reform the city's primaries which were corrupt, disorderly, and violent. Iowa primaries at the time were conducted by local politicians under the provisions of a local option law which the Twenty-seventh General Assembly had enacted in 1898. A tentative effort to correct the evils of the traditional caucus system, the law gave counties the option of holding primary elections. Details varied from county to county-thirty-three counties had adopted primary elections by 1903 - but generally local com-

${ }^{5}$ Brindley, A Study of Iowa Population as Related to Industrial Conditions, 28-29, 54-56, 58. 
mittees of the political parties decided when to hold their primaries, appointed the judges, and counted the ballots.'

Posssessing none of the essential features of a true system of primary elections, the Iowa primaries were little more than thinly disguised caucuses. The abuses to which they were subject were amply demonstrated in the Des Moines primaries where close contests invariably produced widespread fraud: the use of money and whiskey to bribe voters, challenges of voters by partisan judges, personal intimidation and violence, theft of ballots, and fraudulent counting of votes. Most if not all of these abuses attended the city's Republican mayoralty primary on January 18,1904 , which was hotly contested by George Mattern and John MacVicar. "The day and evening were characterized by exciting incidents, which would make a Tammany contest pale into insignificance," the Des Moines Register and Leader reported. MacVicar, the loser, attributed his defeat to "crooked work" by the Mattern forces who controlled the city central committee. Charging that five precincts had been stolen from him, MacVicar complained that voters suspected of favoring him were not allowed to vote in many precincts, while those supporting Mattern voted repeatedly. ${ }^{8}$

Similiar charges and counter-charges marked the Republican Congressional primary in Des Moines and Polk County a few weeks later. This was a bitter race between the incumbent, John A. T. Hull, and his challenger, Judge Solomon F. Prouty, both of Des Moines. When the executive committee of the Polk County Central Committee, which Prouty controlled, refused to publish the names of the election

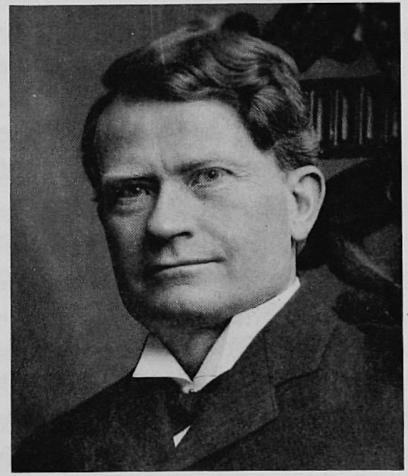

Solomon F. Prouty

'Max D. Perdue, "The Progressive Republicans of Iowa: The Development of the Direct Primary Law 1896-1907” (M.A. Thesis, Drake University, 1965), 3-7, 16 fn.; Des Moines Register and Leader, Jan. 23, 1904.

${ }^{\circ}$ Register and Leader, Jan. 19, 20, 1904. 
judges, Hull accused the committee of conspiring to ignore his nominees and to appoint only Prouty's friends. The committee replied that it had selected representatives of both candidates but was withholding their names because experience had shown that they would be subject to harassment and improper influences if their names were published. Walter Irish, the chairman of the executive committee, was more explicit. He said that if the names of the judges became known, there was "great danger" that they would be "corrupted or bought" by the Hull faction.?

Des Moines was tense on the eve of the primary which took place on February 29, 1904. Each of the two factions swore in 250 special policemen to maintain order at the polls. However, the election was anything but orderly. "From the time the polls opened in the early morning until they were finally closed at night, the day was marred by an endless number of disgraceful scenes," the Register and Leader reported. The two sides quarreled over the seating of judges, accused one another of illegal voting and stuffing the ballot box, and engaged in much violence which nearly resulted in riots in several precincts. In the city hall precinct, the Prouty judges declared that three Hull watchersH. D. Thompson, vice-president of the Des Moines Union Railroad Company, R. H. MacMillan, manager of the Des Moines Edison Light Company, and W. B. Starkey, an attorney-had no right to be there and ordered the Chief of Police, Fred A. Brackett, to throw them out. Brackett did so with such vigor that Thompson, MacMillan, and Starkey indignantly swore out a warrant for his arrest. Complaining that

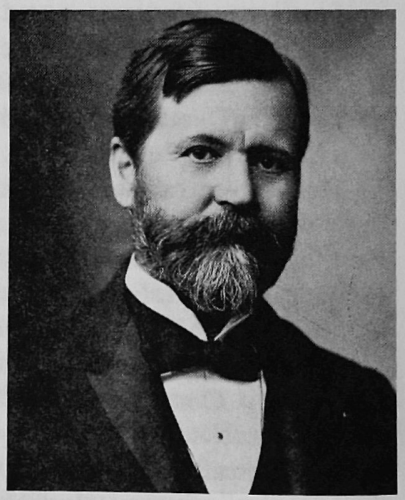

John A. T. Hull 
they had been painfully injured, the three men accused Brackett and his officers of knocking them against the booths and walls and dragging them about the floor. ${ }^{10}$

Such scenes created a mounting sense of public outrage in Des Moines. Describing the city's politics as "disgraceful" and "unspeakably rotten," prominent Des Moines citizens agreed that the city needed a strict primary law. Comparing Des Moines to Sodom and Gomorrah, an angry Des Moines clergyman declared that the Hull-Prouty campaign had been dominated by the wholesale use of money and whiskey to buy votes. He denounced the General Assembly for sitting idly by "in its palace on the hill" and doing nothing to stop the outrages "going on under their very noses." The Polk County Republican convention urged the General Assembly to regulate the state's primaries by specifying the duties of judges, defining the qualifications of voters, requiring prior registration of voters, and penalizing repeated voting. The convention warned that the existing system of unregulated primaries was doing more to undermine respect for law and decency than virtually all other influences combined. "In cities where irresponsible classes are gathered, men are assured by others better entitled to speak than themselves that there are no pains or penalties for crimes committed at a primary election," the convention asserted. "Good government cannot longer stand this strain." $" 1$

On January 26, 1904 Representative Emory H. English, a newspaper editor and publisher of Valley Junction (Polk County), and Senator J. J. Crossley, an attorney of Winterset (Madison County), introduced bills into the Thirtieth General Assembly to reform the primaries. The two men disagreed somewhat on a few points, the principal difference being that Crossley wanted direct nomination by the voters, whereas English favored nomination by a convention of delegates chosen by the voters. Otherwise, their bills were similar. Both proposed to place primary elections under state control: to make them compulsory throughout Iowa and to subject them to all of the legal requirements governing general elections. 
The officials who conducted general elections were also to supervise the primaries; voters must register their party affiliation in order to participate in the primaries; all political parties must hold their primaries on the same day; the Australian ballot must be used in the primaries as well as the general elections; and severe penalties were to be imposed on those found guilty of bribery, fraud, or intimidation. ${ }^{12}$

The Crossley and English bills stirred up a lively debate among Iowa newspaper editors and politicians regarding the political morality or immorality of Des Moines and the rest of the state respectively. Opponents of the two bills argued that Des Moines was the only place in Iowa that needed or wanted regulated primaries. They saw no reason why the rest of the state should be burdened with a cumbersome and unnecessary set of regulations merely because the Des Moines primaries were corrupt. Proponents of the Crossley and English bills replied that the smaller cities, towns, and rural districts of the state needed regulated primaries quite as much as Des Moines did. They said that the excesses of the Des Moines primaries were duplicated on a smaller scale in rural precincts throughout Iowa whenever bitter rivalry produced close races. "No man who has observed country political matters for a term of years but what will say that whenever there is bitterness engendered or intense rivalry created by political factions there is corruption at the primaries no matter whether it is Polk County or Guthrie County," commented the Stuart Herald. It added that safeguarding the primaries was even more important than regulating general elections in the counties of central Iowa where victory in the Republican primaries was generally tantamount to election. ${ }^{13}$

The drive for statewide reform of primary elections failed on March 30 when the Senate rejected the Crossley bill by a vote of twenty-five to nineteen. The Register and Leader ascribed the bill's defeat to the opposition of rural communities and "places where the old caucus system has been well

${ }^{12}$ Thirtieth General Assembly of Iowa, Journal of the House (Des Moines, 1904), iv-v; Journal of the Senate (Des Moines, 1904), iv-v; Register and Leader, Jan. 27, 1904.

${ }^{13}$ Register and Leader, Jan. 20, Feb. 6, 11, March 18, 23, April 4, 10, 1904. The Register and Leader reprinted editorials from other Iowa newspapers on the pros and cons of statewide primaries, including the one from the Stuart Herald quoted above. 
oiled and in good working order." However, many members of the General Assembly, including a number of those who opposed statewide primaries, recognized the need to cleanse the Des Moines primaries and were ready to help the city put its house in order. Representative N. E. Kendall, a lawyer of Albia (Monroe county), expressed this view when he said that anyone who had been around Des Moines during the last ten years knew that the city's primaries needed to be cleaned up. ${ }^{14}$

Deciding to take what they could get, English and Senator Cassius C. Dowell of Des Moines, who sponsored the English bill in the upper house, restricted the bill to counties with more than 75,000 inhabitants. This limited the bill's application to Polk County, the only county in Iowa with more than 75,000 people. The House and Senate then passed the amended English bill with the approval of Governor Albert B. Cummins. The Register and Leader remarked that even opponents of all primary legislation were willing to experiment with Polk County, "upon the cheerful theory that nothing can be done to make matters worse." 15

The divisions created by the struggle over statewide primaries, which was renewed when the Thirty-first General Assembly convened in 1906, were mainly conservative and liberal (standpat and progressive in the political terminology of the time) rather than rural and urban. Yet rural distrust and fear of the cities was an important source of opposition to state regulation of primary elections. A leading foe of such regulation, Senator Shirley Gillilland, an attorney of Glenwood (Mills county), feared that statewide primaries would lead to plurality nominations which would allow cities, the centers of political corruption, to dominate Iowa politics. This would "turn loose on the people the slums of such cities as Des Moines," Gillilland predicted. Political bosses in the state's half-dozen largest cities, "with their saloons and gambling dens and brothels," would be able to control the nominations of both parties. Gillilland's charges now seem demagogic but at the time they reflected a genuine rural fear that state regu- 
lation of primaries would enable the cities and larger towns to control the nomination of candidates. ${ }^{16}$

Iowa was comparatively free from the industrial warfare that embittered the relations of capital and labor in a number of states at the turn of the century. Charles F. Wennerstrum, the Commissioner of the Iowa Bureau of Labor Statistics (1900-1902), attributed the relatively peaceful relationship of capital and labor in Iowa to the "conciliatory attitude" of both and to the fact that Iowa was not as heavily industrialized or urbanized as some of the eastern states where much of the industrial violence occurred. Yet Iowa was by no means immune to the strife and turmoil that accompanied the rise of organized labor. Between June 30, 1894 and December 31, 1900, Iowa experienced 381 strikes involving 32,930 strikers and 831 factories, mines, and shops. Wage disputes were the most common cause of the strikes: the strikers were either resisting cuts in wages or demanding higher wages. ${ }^{17}$

THE LABOR MOVEMENT in Iowa had become a force to be reckoned with by 1900 when it included forty-eight crafts with 396 local unions in eighty-eight localities of the state and a total membership of 26,068 . The rapid growth of trade unionism plus the return of prosperity induced some Iowa manufacturers to accept the unions' demands for recognition, collective bargaining, and trade agreements. Edward D. Brigham, who succeeded Charles F. Wennerstrum as Commissioner of the Iowa Bureau of Labor Statistics, included copies of sixtyseven trade agreements in thirty-eight crafts in his biennial report to Governor Cummins on October 1, 1903. Noting that these were by no means all of the trade agreements negotiated in Iowa in 1902-1903, Brigham said that he had selected only the agreements which affected large numbers of employers and employees. He explained that he had included the agreements to show "the business understanding" that existed be-

${ }^{16}$ Thirty-first General Assembly of Iowa, Journal of the Senate (Des Moines, 1906), iv-v; Register and Leader, Jan. 27, 30, Feb. 15, 19, 1906; Perdue, "The Progressive Republicans of Iowa: The Development of the Direct Primary Law 1896-1907," 37-38, 60.

${ }^{17}$ Iowa Bureau of Labor Statistics (IaBLS), Ninth Biennial Report, Iowa Documents, 1902 (Des Moines, 1901), IV, 22-25, 175, 272-323, 326-327, 332, 334-335. 


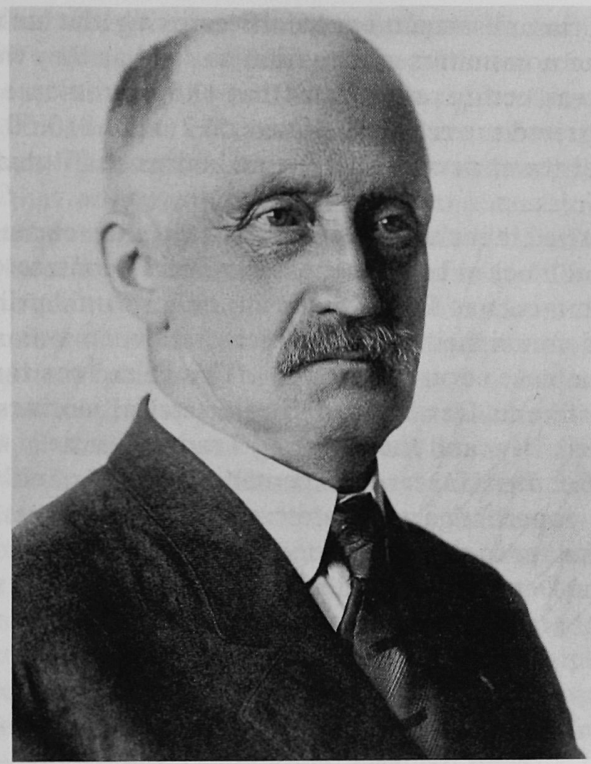

Charles F. Wennerstrum

tween employers and employees in Iowa. ${ }^{18}$

The trade agreements varied considerably, but a number of them included the closed shop as well as schedules of hours and wages. The Boss Bakers of Dubuque, for example, contracted to employ only members of the Journeymen Bakers' and Confectioners' International Union, Local Number 302. The union, in turn, authorized the bakers to use the union label on all their products, promising to furnish the label at cost. The two sides also agreed on a scale of wages ranging from $\$ 12$ to $\$ 18$ a week and a ten-hour day. The newspaper proprietors and printers of Boone entered into a similar agreement with the International Typographical Union of America, Local Number 381. The contract allowed the newspaper proprietors and printers to use the typographical union label;

${ }^{18}$ IaBLS, Ninth Biennial Report, 26, 175, 198-199; Tenth Biennial Report, Iowa Documents, 1904 (Des Moines, 1904), IV, 5, 270-381. 
specified that all employees in offices using the union label must become members of the union as soon as they were eligible for membership; stipulated that shop foremen and journeymen printers were to be paid $\$ 12$ and $\$ 10.50$ a week respectively; and provided that nine hours constituted a day's labor. ${ }^{19}$

Organized labor's pursuit of the closed shop encountered a major roadblock when the boss butchers, contractors, and master plumbers of Des Moines announced on April 1, 1904 that henceforth their shops, which had been union shops, would be open to non-union labor. This raised the threat of a general strike in Des Moines. The electrical workers walked out immediately, and the Building Trades' Council, which included the bricklayers, carpenters, lathers, millworkers, painters, paperhangers, plasterers, and steamfitters, met to decide whether to attempt a general strike. J. B. Nesbit, president of the Des Moines Trades and Labor Assembly, said that he did not see how the unions could tolerate non-union labor. "It is not right for the men who pay no dues and have been at no expense to build up wages and shorter hours to get the same results as the men who are bearing the brunt of labor's struggles," Nesbit declared. ${ }^{20}$

The general strike did not materialize. The carpenters and millmen returned to work when the contractors assured them that while they intended to hire whom they pleased, they had no intention of discriminating against the unions in employment, hours, wages, or working conditions. The resulting collapse of the general strike was a victory for the Des Moines Business Men's Association which was behind the open-shop movement. Des Moines businessmen had successfully challenged the right of the unions to control the labor market. ${ }^{21}$

Despite setbacks, the labor movement created a new spirit of independence and self-reliance among the industrial workers of Iowa. Unionization was not only a means of achieving higher wages, shorter hours, and better working conditions; it was also a means of achieving dignity, respect, and selfimprovement. "Organization secures more respect for us, we

${ }^{19}$ IaBLS, Tenth Biennial Report, 272, 329-330.

${ }^{20}$ Register and Leader, April 2, 1904.

${ }^{21}$ Ibid., April 2, 5, 6, 1904. 
are regarded now like men instead of conveniences," reported Leather Workers' Union Number 11 of Davenport. Machinists' Union Number 254 of Des Moines, describing the unorganized machinists of the previous generation as "silent automatons, gloomy, taciturn, and non-cummunicative," declared that organization had aroused the machinists from their lethargy, enabling them to develop their "latent powers" through association, discussion, and education. The miners' and teamsters' unions reported similar results, noting that their members had become more productive workers and more responsible citizens. Mine Workers' Union Number 991 of Angus stated that organization had caused its members to read and to think more seriously about labor questions and other public issues, while Team Drivers' Union Number 90 of Des Moines commented that its members had shown marked improvement, "socially, morally and industrially," since organization. ${ }^{22}$

The rising demands and expectations of organized labor created strong public resentment in some Iowa communities. In seeking to attract new industries, cities and towns sometimes listed public hostility to labor agitation as one of their industrial assets. The Commercial Club of Keokuk said that labor troubles were "practically unknown" in local industry. "The controlling spirits of organized labor [in Keokuk] are conservative and public sentiment is overwhelming against such antagonism as happens elsewhere," the club declared. Council Bluffs advertised "an abundance of practically unorganized help," while Tama offered cheap labor "free from union disturbances." Shenandoah also had cheap labor, "still a good grade of it, consisting of no foreign or disturbing element, and no negroes." There were no labor unions in Shenandoah; the community would not tolerate them. ${ }^{23}$

Higher wages and shorter hours were uppermost in the minds of Iowa wage-earners but they were also concerned about the dangerous and unsanitary conditions under which many of them worked. They had good reason to be concerned, 
for Iowa was one of the few states in the nation in 1900 that had virtually no laws or regulations to protect the health, comfort, and safety of factory workers. The Commissioner of the Iowa Bureau of Labor Statistics could inspect factories but only to obtain information. If he found unsatisfactory working conditions, he could recommend improvements, but he had no power to enforce his recommendations. ${ }^{24}$

Charles F. Wennerstrum was the first Commissioner of Labor in Iowa to inspect factories. Fortified by an opinion of the Attorney General of Iowa that the Commissioner of Labor had the authority to inspect factories when he could not obtain satisfactory information by correspondence, Wennerstrum visited 328 factories and shops employing five or more persons each between June 1900 and the following February. Although he thought that working conditions in these plants were "fairly satisfactory" on the whole, Wennerstrum said that conditions in a number of factories were too dangerous and dirty to be tolerated. He found $\mathbf{2 7 0}$ factories two or more stories high with no fire escapes, 135 with unsanitary toilets, 113 that were badly ventilated, ninety-eight with dangerous machinery, and seventeen with open elevator wells. If the 328 plants inspected by Wennerstrum were representative of the 4,828 factories in Iowa in 1900 , working conditions in some two-thirds to threefourths of the state's factories were hazardous to the health and safety of the workers. ${ }^{25}$

The most immediate threat to the lives of Iowa factory workers was unguarded machinery. Of the 2,604 recommendations made by the Iowa Bureau of Labor Statistics for the improvement of working conditions during the years 1901-1905, 965 called on employers to place guards on dangerous machinery. Protruding set screws on revolving shafts; unboxed drive belts; cogs, gears, planers, saws, and wheels without hoods or other safeguards; grinding, buffing, and polishing machines with no suction fans or blowers to carry off the gaseous dust, sparks, and splinters given off by the ma-

${ }^{24}$ IaBLS, Ninth Biennial Report, 8-9, 361-363, 365; E. H. Downey, History of Labor Legislation in Iowa, ed. Benjamin F.Shambaugh, Iowa Economic History Series (Iowa City: State Historical Society of Iowa, 1910), 105-106, 193-205.

${ }^{25}$ IaBLS, Ninth Biennial Report, 8-9; Downey, History of Labor Legislation in Iowa, 95, 105-106. 
chines; uninspected boilers: all exposed the workers tending them to the constant threat of death or injury. A fifteen-yearold boy employed by the Agar Packing Company in Des Moines was pulled into an unguarded overhead revolving shaft and torn to pieces when the whip he was using to drive pigs up a chute became entangled in the shaft. A laborer in a sash and door factory died when he was hit by a board thrown from a circular saw. A workman in a flour mill was killed when his clothing caught in the mill's machinery which tore off his arm. A boiler explosion in a glucose factory killed five workmen. Accidents were commonplace in the Oelwein railroad shops: "An apprentice lost a finger on the guide grinding machine; a machinist lost two fingers and part of his hand on reversing gear of planer; a laborer had his foot crushed on transfer table; a fire knocker had his arm cut off in clinker pit by locomotive; and a machinist lost an arm in the round house." 26

Fire was an even greater potential threat to factory workers, for many if not most of the state's factories had no fire escapes. Of the 290 factories with two or more stories that Wennerstrum visited in 1900-1901, only twenty provided fire escapes. Some of these buildings were three, four, and even six stories high with as many as $225 \mathrm{employees.} \mathrm{Compounding} \mathrm{the}$ fire hazard were doors that opened inward, creating the danger of a jam in case of a sudden alarm or panic, and stairways with locked gates that left men, women, and children with virtually no alternative except to jump out the windows. Noting that it was the responsibility of cities and towns to require and to regulate the construction of fire escapes, Wennerstrum declared that local authorities had been "almost criminally negligent with respect to factories." Calling for stringent state legislation to compel factory owners to equip their buildings with fire escapes, Wennerstrum warned against waiting "until a holocaust horrifies the state." ${ }^{27}$

Adding to the distress of many Iowa factory workers were insufficient heat (none at all in some cases), poor light, and

${ }^{26}$ IaBLS, Ninth Biennial Report, 16-20, 38-74; Tenth Biennial Report, 17-19, 55-64, 490; Downey, History of Labor Legislation in Iowa, 96-98, 103, 107-108; Register and Leader, Jan. $28,1904$.

${ }^{27}$ IaBLS, Ninth Biennial Report, 8-9, 15-16, 38-74; Tenth Biennial Report, 17-22; Downey, History of Labor Legislation in Iowa, 98-100. 
bad ventilation. Wennerstrum found "dozens" of ironworks where the furnaces and forges supplied the only heat available to the ironworkers. Some box factories and planing mills were also unheated, lacking even a stove to warm the workers who suffered intensely from the cold. Some new factories were well lighted and well ventilated, having been built with high ceilings and large windows and equipped with artificial ventilation. But workrooms in most of the older plants, which had been built with low ceilings and small windows, were dank, dark, and unventilated except for the fresh air that filtered in through cracks and holes in the building. Foul air was an even greater danger in the iron foundries where furnaces, forges, and anvils produced a combination of smoke and fumes that damaged eyes and lungs alike. E. H. Downey, a contemporary student of working conditions in Iowa factories, reported that he had visited "more than one large foundry where the smoke was so thick that it was difficult to see across the work room on a winter day." ${ }^{28}$

A further hazard to the health of many Iowa wage-earners was the indifference of their employers to the most elementary sanitary precautions. Employees of printing shops complained of the foul odors generated by the accumulation of layers of tobacco spit and dust on unscrubbed floors. "Little or no attention is paid to sanitary conditions," a Des Moines printer remarked. "Many of the best shops have dirt and filth sticking to the floors one-fourth to one inch thick." Wennerstrum thought that the need to clean up the state's factories and workshops was no less urgent than the need to build fire escapes and to install guards on dangerous machinery. He reported that many plants were so filthy that they were "exceedingly dangerous" to the health of the communities in which they were located as well as that of their employees. ${ }^{29}$

Wennerstrum was especially disturbed by the condition of factory "water closets" which he termed "generally defective in the extreme." Stressing the urgent need for legislation to require factory owners to provide clean toilets, Wennerstrum

${ }^{29}$ IaBLS, Ninth Biennial Report, 8-9; Tenth Biennial Report, 491. 
stated that thirty-seven percent of the factories that he inspected lacked decent accommodations. The toilets were so filthy in some cases that employees refused to use them. Many were outdoor privies, while others were even more primitive. A car repairer in the Missouri Valley railroad shops reported that the toilet in his shop consisted of "an open pit, with a rail across the top and it has not been cleaned in ten years, or disinfected." A Missouri Valley machinist was even more emphatic about the facilities in his shop: "water closets unfit for hogs to go to." 30

Wennerstrum was also incensed by the failure of numerous manufacturers to provide separate toilets for their male and female employees. Of the 503 improvements in working conditions that Wennerstrum and Brigham recommended to employers in 1901-1902, 120 called for separate toilets for women. One of the factories that Wennerstrum visited had only one toilet with no lock for the twenty-three men and forty women working in the plant. When Wennerstrum protested such "flagrant disregard of the decencies," the owner replied that the men and women in his factory were like members of a family and did not need separate toilets. ${ }^{31}$

Not all Iowa factories were dangerous and unsanitary. Wennerstrum's inspection report, which summarized conditions in each of the plants he visited, included such notations as "A model institution," "The best of its kind," "A fine plant," "Moving into new model factory," "Ideal factory," and "Everything the best that can be had." Even when it was necessary to recommend improvements in working conditions, Wennerstrum reported that some manufacturers were taking steps to protect the comfort, health, and safety of their workers. The steps varied from factory to factory but included bathrooms, gymnasiums, and reading rooms; free insurance of employees against industrial accidents to the amount of $\$ 10,000$ for each employee; arrangements for the employer to pay the expenses and wages of injured employees while they were unable to work; rules forbidding employees to clean 
machinery while it was in motion and fines for those violating the rules. However, such expressions of employers' concern for the welfare of their employees were the exception rather than the rule. ${ }^{32}$

How much Iowa wage-earners suffered from dangerous machinery, foul air, and accumulated filth will never be known, but it is clear that they paid a high "blood tax" (to use a contemporary term) for the state's industrial growth. Edward D. Brigham, the first Commissioner of the Iowa Bureau of Labor Statistics to make a systematic effort to collect accident statistics, reported that industrial accidents in Iowa killed sixty-eight workmen and injured 2,325 others between December 31, 1900 and January 1, 1906. However, these figures, as Brigham pointed out, were little more than the tip of the iceberg. They did not include mining and railroad accidents, which were reported separately by the State Mine Inspectors and the State Board of Railroad Commissioners. Nor did they come close to including all of the accidents in the state's factories and shops, for Iowa did not require manufacturers to report accidents. Brigham's figures, therefore, were limited to the accidents that he discovered through factory inspection plus those that manufacturers voluntarily reported on the statistical blanks that Brigham sent them. Since the annual inspections of the Bureau of Labor included no more than one-fifth of the state's factories at most, and since many manufacturers (forty-five percent in 1902) did not return the bureau's statistical blanks, Brigham's statistics were fragmentary at best. ${ }^{33}$

Writing several years later, E. H. Downey called the accident records of the Iowa Bureau of Labor Statistics "notoriously incomplete." Citing the number of accidents reported in

${ }^{32}$ IaBLS, Ninth Biennial Report, 66-74.

${ }^{33}$ IaBLS, Tenth Biennial Report, 25-26, 383-388; Eleventh Biennial Report, Iowa Documents, 1906 (Des Moines, 1906) IV, 9-11, 78-88; Twelfth Report, 26-41; Downey, History of Labor Legislation in Iowa, 100-101. To realize the tragic dimensions of the problem of industrial accidents in Iowa, it is necessary to combine the accident reports of the State Bureau of Labor Statistics, the State Mine Inspectors, and the State Board of Railroad Commissioners. The combined reports of the three agencies for the seven years, 1905-1911, show, for example, that factory, mine, and railroad accidents killed 884 Iowans and injured 20,450 others. Wayne O. Dailey, Jr., "The Relationship of Progressivism to the Iowa Workmen's Compensation Act of 1913," (M.A. Thesis, Drake University, 1967), 40-42. 
states which insured their workers against industrial accidents, Downey thought that the actual number of accidents in the factories and shops of Iowa was two or three times greater than the number reported by the state's Bureau of Labor Statistics $(3,351$ in 1910). He estimated that the number of Iowa factory workers suffering injuries resulting in more than one week's disability ran into the thousands every year. ${ }^{34}$

No group of Iowa factory workers suffered more from adverse working conditions than the women and children. Iowa had no laws regulating the labor of women and children in 1900 except in coal mining where the state prohibited the employment of women and girls and the labor of boys less than twelve years old. The number of women and children employed in the factories and shops of Iowa was not large by national standards. In 1900, Iowa ranked twenty-third nationally both in the number of women wage-earners sixteen years old or older and in the number of child laborers under sixteen. Yet the number of women and children employed by Iowa manufacturers was growing at the turn of the century. The social cost of their labor was as high proportionately as it was anywhere in the nation. ${ }^{35}$

In Iowa as in other states, improved machinery and the subdivision of labor lessened the need for human muscle and skill, causing many manufacturers to hire women and children instead of men. The United States Bureau of the Census reported in 1900 that the number of women engaged in manufacturing in Iowa increased ninefold, and the number of children threefold, between 1870 and 1900 . The number of women wage-earners sixteen years old or older grew from 951 in 1870 to 1,431 in $1880,5,183$ in 1890 , and 8,248 in 1900 . The number of child laborers under sixteen rose from 686 in 1870 to 1,559 in $1880,1,644$ in 1890 , and 1,888 in $1900 .^{36}$

The Census Bureau subsequently revised these figures up-

${ }^{34}$ E. H. Downey, History of Work Accident Indemnity in Iowa, ed. Benjamin F. Shambaugh, Iowa Economic History Series (Iowa City: State Historical Society of Iowa, 1912), 8-9.

${ }^{35}$ Downey, History of Labor Legislation in Iowa, 110-113; Thomas B. Fitzgerald, "A History of Child Labor Legislation in Iowa, 1874-1915,” (M.A. Thesis, Drake University, 1970), chs. I, II; Twelfth Census of the U.S., VII, cxxx.

${ }^{36}$ Fred E. Haynes, "Child Labor Legislation in Iowa," in Iowa Applied History Series, ed. Benjamin F. Shambaugh, II (Iowa City: State Historical Society of Iowa, 1914), 561-562, 577-582; Twelfth Census, VII, cxxx. 
The Annals of Iowa

ward in a special report on occupations in 1900. This study, which was published in 1904, reported that the number of women employed in manufacturing and "mechanical pursuits" in Iowa rose from 8,436 in 1880 to 21,286 in 1900 , raising the proportion of women laborers in the state's factories and shops from twelve percent in $\mathbf{1 8 8 0}$ to seventeen percent in 1900 . The study did not report how many children worked in the manufacturing industries of Iowa prior to 1900 , but it stated that the number of children ten to fifteen years old engaged in all occupations in Iowa-agriculture, professional service, domestic and personal service, trade and transportation, and manufacturing and mechanical pursuits-grew from 20,294 in 1880 to 29,410 in 1900 . These totals included 17,832 boys and 2,462 girls in 1800 and 24,564 boys and 4,846 girls in 1900. In the latter year, more than three-fourths of the boys $(78 \%)$ were agricultural laborers, while approximately the same proportion of girls $(79 \%)$ worked in domestic and personal service. Manufacturing and mechanical pursuits ranked second as a source of employment for both boys and girls in 1900 when some nine percent of the boys $(2,120)$ and ten percent of the girls (501) worked in the factories and shops of Iowa. ${ }^{37}$

Women and children labored in most branches of Iowa manufacturing but tended to concentrate in the consumergoods industries. The greatest concentration of women wageearners was in the clothing industry where they outnumbered the men, 1,355 to 229 . Women comprised $62 \%$ of the workers in confectionery; $54 \%$ in patent medicines; $51 \%$ in leather gloves and mittens; $44 \%$ in woolen goods; $41 \%$ in boots and shoes; $37 \%$ in food preparations; $33 \%$ in canning and preserving fruits and vegetables; $33 \%$ in cigars and cigarettes; $32 \%$ in buttons; $26 \%$ in printing and publishing; and $21 \%$ in bread and other bakery products. Child laborers were most numerous in canning and preserving fruits and vegetables, cigars and cigarettes, planing-mill products, printing and publishing, and wholesale slaughtering and meat packing. ${ }^{38}$

${ }^{37}$ United States Bureau of the Census, Special Reports: Occupations at the Twelfth Census, (Washington, 1904), xcii-xciii, c-ci, cxxii-cxxiii, cxxix, cxLviii, cLii-cLiii, cLx.

${ }^{38}$ IaBLS, Eleventh Biennial Report, 412-415. 
Iowa's Industrial Roots: Some Social and Political Problems

Women and children generally worked the same number of hours as men but received only one-half to one-third of men's wages. In $1902,1,627$ of Iowa's 4,000 or so manufacturers reported that they employed 11,812 women and 2,630 children and that each group worked nine and one-half hours a day on the average. This corresponded to the number of hours that most men worked at the time. The average length of the work day for forty-nine of the fifty-eight trade unions in Iowa in 1903-1904 ranged from eight to ten hours. ${ }^{39}$

The average annual earnings of the men, women and children who worked in the manufacturing industries of Iowa in 1900 were $\$ 452, \$ 214$, and $\$ 143$ respectively. The wages of each of the three groups rose during the next few years, but the differential remained about the same. In 1906, for example, the owners of 882 industrial plants in 66 counties of Iowa reported that they employed 29,488 wage-earners in 1905: 24,060 men, 4,645 women, and 783 children. The average annual earnings reported by the manufacturers were $\$ 550$ for the men, $\$ 258$ for the women, and $\$ 163$ for the children. ${ }^{40}$

The evils of child labor are amply documented in the reports of Wennerstrum and Brigham, but neither said much about the impact of industrial labor on women. This may have been due to their preoccupation with the plight of the children, but it is clear in any case that the two Labor Commissioners regarded child labor as the more immediate problem. They expressed concern from time to time about the health and safety of women wage-earners, but they did not deal with the problems of the women apart from their general recommendations to improve working conditions. However, both men saw clearly that child labor was one of the worst social evils of modern industrialism, and both advocated state intervention to protect the children.

It seemed strange to Wennerstrum that "a progressive state like Iowa" lagged behind the "more advanced" states in protecting children from the dangers of industrial labor. He found that the tasks of the children, many of whom were no

${ }^{39}$ IaBLS, Tenth Biennial Report, 22-23, 385-390; Eleventh Biennial Report, 198-199.

${ }^{40}$ Twelfth Census, VII, cxv-cxvi; IaBLS, Eleventh Biennial Report, 412-415; Twelfth Report, 216. 
more than ten years old, frequently were hard and laborious. They received no concessions on account of their age, working the same number of hours as adults. ${ }^{41}$

"I took special pains to observe the physical condition of the children that I found working in the factories, and they impressed me by their wan and overworked condition," Wennerstrum reported. "In many instances they were in a rundown condition and seriously weakened." Not only was the physical health of the children impaired, but their mental and moral growth had been stunted as well. A number of the children had never attended school, while others had attended only a short time and had little knowledge of books. Noting that thirteen states had established fourteen as the minimum age for child labor, Wennerstrum called for a similar restriction in Iowa "for humanitarian reasons if for no other." ${ }^{2}$

Brigham was equally disturbed by the plight of the factory children whose appearance he described as "pathetic in the extreme, surrounded as many were with the dirt and grime of their employment." To see children working under such conditions without being able to help them made the work of factory inspection difficult and distressing. Brigham was further dismayed by the rapid increase in child labor, noting that the number of working children reported to the Iowa Bureau of Labor Statistics had jumped from 687 in 1896 to 2,630 in 1902 , an increase of $322 \%$ in six years. He thought that the actual rate of increase was even higher, since the number of child laborers reported by the Bureau in 1902 was based on a small number of factory inspections and voluntary reports from barely half of the state's manufacturers. Estimating that the actual number of children employed in Iowa factories in 1902 was double the number reported, Brigham warned that if the employment of children continued to accelerate at the current rate, it could only result in a rapid increase in the rates of illiteracy, invalidism, and pauperism among the state's children, to say nothing of those who were permanently crippled and maimed. ${ }^{43}$

${ }^{41}$ IaBLS, Ninth Biennial Report, 20-21.

${ }^{42}$ Ibid., 21-22.

${ }^{43}$ IaBLS, Tenth Biennial Report, 22-23, 390, 446-448; Downey, History of Labor Legisla. tion in Iowa, 114-116, 121. 
Brigham also complained that manufacturers were attempting to circumvent the Iowa Factory Act of 1902 which specified that no child under sixteen years of age should be allowed to operate any kind of dangerous machinery. Brigham charged that some manufacturers were trying to get around the law and to protect themselves from liability for injuries by requiring children and their parents to sign a "Release Form for Child Employment" as a condition of employment. The form stipulated that the child was "fully competent" to do the work for which he was applying; that he had previously worked in occupations requiring the use of dangerous machinery and understood the hazards of such work; that he assumed responsibility for any injuries that he might suffer and waived the dangers "incident to the manner in which such machinery is constructed, guarded or operated." Angrily denouncing use of the form as "practically a criminal conspiracy" to hire children to operate dangerous machinery in violation of the law, Brigham declared that such subterfuges furnished further evidence, if any were needed, of the immediate need for state regulation of child labor. ${ }^{44}$

THE PUBLIC RESPONSE to the social problems of industrialization in Iowa, as in other states, produced the social justice movement, a constituent part of the Progressive reform movement that emerged in the early 1900 s and soon became the dominant issue in American politics. Previous attempts to achieve labor and welfare legislation in Iowa had been largely abortive because Iowans generally were not yet aware of the need for such legislation. The labor unions opened the campaign for social legislation in Iowa, but they were soon joined by organizations of professional people and various women's groups. In some cases, notably the drive to regulate child labor, much of the impetus came from national organizations seeking uniform state legislation as a means of resolving the incongruity between a national economy based on interstate markets and a federal system of government in which the

${ }^{41}$ IaBLS, Tenth Biennial Report, 23-25; Downey, History of Labor Legislation in Iowa, 116-117. 
states dealt mainly with social problems. ${ }^{45}$

Organized labor's drive for social legislation in Iowa was led by the State Federation of Labor, which was organized in 1893 by fifty-two delegates representing nineteen unions and trades assemblies in Burlington, Davenport, Des Moines, Dubuque, Ottumwa, and Sioux City. The delegates explained that they had assembled "in the cause of Labor Emancipation." They proposed to organize a State Federation of Labor in order to unite the labor organizations of Iowa in a common struggle to achieve equal rights and privileges for wage-earners. The Federation would work for "needed industrial and social reforms" through state and federal legislation. ${ }^{46}$

The Federation accomplished little in the 1890 s, for it was soon engulfed by the Panic of 1893 and the hard times which followed. Beset by declining membership and an empty treasury, the Federation was hard put to survive. The secretarytreasurer estimated in $\mathbf{1 8 9 5}$ that the Federation had lost forty percent of its affiliated organizations and fifty percent of its individual membership. The Federation did not meet in 1896, and only sixteen delegates attended the annual convention in 1897. Attendance at the convention dropped to twelve delegates in 1898 when unions throughout Iowa were described as "listless and indifferent" because of the depression and the Federation's inability to achieve legislative reforms. The ineffectiveness of the Federation was due, in turn, to the failure of affiliated unions to pay their dues. ${ }^{47}$

The fortunes of the Federation turned upward in 1899 and 1900 when the return of prosperity revived the moribund labor movement. Under the leadership of President Arthur E. Holder (1901-1903), an able and energetic organizer, the Fed-

${ }^{45}$ For an excellent discussion of the problems that social reformers encountered in attempting to reconcile economic nationalism and political federalism, see William Graebner, "Federalism in the Progressive Era: A Structural Interpretation of Reform," The Journal of American History, LXIV, No. 2 (September 1977), 331-357. Graebner argues that the crux of the social reform problem was the fear that states which restricted the labor of children, limited the hours of working women and children, established minimum wages for women and children, compensated injured workers for industrial accidents, and the like would place their industries at a competitive disadvantage with those of states which did not adopt such reforms.

${ }^{46}$ Loren Stuckey, The Iowa State Federation of Labor, ed. F. E. Haynes, Studies in Sociology, Economics, Politics, and History, Research Bulletins of the University of Iowa (Iowa City, n.d.), 16-17, 23, 29. Stuckey carried his study to 1914; the card catalogue of the library, Division of Historical Museum and Archives, Des Moines, lists the date of publication as 1917.

${ }^{47}$ Ibid., 23, 29-32. 
eration sponsored the organization of 175 new local unions. The affiliation in 1902 of the United Mine Workers, Iowa's biggest union with eighty-three locals and some 12,000 members, gave the Federation another powerful boost. The Federation was now strong enough to exercise effective pressure in behalf of labor legislation. Beginning in 1900, the Federation's legislative committee lobbied each session of the General Assembly. ${ }^{48}$

The Federation's legislative program was broad and diverse, ranging from federal restriction of immigration to municipal ownership of electricity, gas, street railways, water, and telephone and telegraph systems. ${ }^{49}$ But the Federation worked mainly to enlist federal and state support in two areas: (1) equality of opportunity, a traditional goal of American labor, and (2) better working conditions to protect the health, safety, and welfare of wage-earners. The state laws that the Federation sought were similar in many respects to those advocated by Wennerstrum and Brigham.

To achieve equal opportunity for laborers and their families, the Federation sought a series of federal and state laws to promote vocational education, to facilitate employment, and to eliminate discrimination, particularly against women and children. The Federation called on the federal government to cooperate with the states in promoting instruction in agriculture, home economics, and industrial arts in secondary schools and in supporting extension departments in state colleges of agriculture and mechanic arts. The Federation urged the General Assembly to prohibit the labor of children under fourteen in factories, mines, stores, and workshops; to require children under sixteen to attend school throughout the school year and to furnish free textbooks; to support the establishment of public trade schools and the development of extension courses by the Engineering Department of Iowa State College; and to establish a state employment bureau. The Federation advocated women's suffrage, asserting that the "best interests" of labor required the admission of women to "full citizenship" both as a matter of justice and as a means of raising 
the wages of all laborers. To protect free labor from the unfair competition of cheap convict labor, the Federation demanded the abolition of Iowa's traditional contract convict labor system whereby the state leased the labor of convicts to contractors. ${ }^{50}$

The Federation drew heavily on the reports and recommendations of Wennerstrum and Brigham in seeking factory legislation to protect the health and safety of wage-earners. It pressured the General Assembly to regulate heating, lighting, sanitation, ventilation, the construction of fire escapes, the installation of guards on dangerous machinery, the inspection of boilers, the reporting of industrial accidents, and the compensation of workers injured in industrial accidents. Emphasizing the need to expand and strengthen factory inspection, the Federation urged the General Assembly to increase the appropriations and staff of the Bureau of Labor Statistics and to empower the Bureau's factory inspectors to enforce their recommendations. ${ }^{51}$

Leaders of the Federation realized from the first that they must build a broad base of popular support if they were to secure the enactment of labor legislation. Consequently, the Federation worked systematically to foster public appreciation and understanding of its goals. Presidents of the Federation, such as A. L. Urick (1903-1913), regularly discussed the needs and problems of organized labor before groups of churchmen, educators, social workers, and women. Keenly aware of the influence of the press, the Federation cultivated friendly relations with the newspapers and encouraged the establishment of a labor press. In 1904, the Federation undertook to distribute monthly bulletins of labor news to the newspapers, but the project proved to be too ambitious and had to be dropped. However, the Federation published numerous pamphlets to explain its position on particular issues. During the struggle to regulate child labor, for example, the Federation distributed 21,000 copies of four pamphlets to legislators, superintendents of schools, trade unions, women's federations, and 365 newspapers. ${ }^{52}$ 
Allied with the Federation were various socially-minded groups whose aims and interests overlapped those of organized labor at numerous points. Organizations like the Iowa Federation of Women's Clubs, the State Mothers' Congress (similar in character and purpose to today's Parent-Teachers' Association), the State Teachers' Association, and the Women's Christian Temperance Union, no less than the Federation of Labor, formed the vanguard of the social reform movement in Iowa. The teachers' and women's groups broadened the base of the movement and made it more truly a social justice movement. The reform motives of organized labor were both humanitarian and selfish. The labor unions certainly were interested in social justice but they also had a vested interest in many of the reforms which they advocated. The motives of the teachers and women, on the other hand, were largely disinterested and idealistic.

The Teachers' Association, Women's Clubs, W.C.T.U., and the Federation of Labor, supported by the Labor Commissioners and the State Superintendents of Public Instruction and by sympathetic newspapers like the Register and Leader, led the twin campaigns for compulsory education and control of child labor. They lobbied the General Assembly and conducted petition campaigns to arouse public opinion. Their initial efforts were only partly successful. They persuaded the General Assembly in 1902 to enact Iowa's first compulsory education law, which required children between the ages of seven and fourteen to attend school twelve consecutive weeks during the school year. Two years later, the General Assembly extended the period of compulsory attendance to sixteen consecutive weeks. However, the General Assembly refused to pass the child labor bills that labor, teachers, and women supported in 1902 and 1904 because of the opposition of country districts, small towns, and such special interests as the button manufacturers and the canners who insisted that child labor was essential to their profitable operation. ${ }^{53}$

The growth of the social justice movement in Iowa as in

${ }^{53}$ Ibid., 42, 99-100; Fitzgerald, "A History of Child Labor Legislation in Iowa, 1874-1915," chs. III, IV; Downey, History of Labor Legislation in Iowa, 117-135; Haynes, "Child Labor Legislation in Iowa," 591-595. 
other states was marked by increasing cooperation between national and state organizations as the movement spread across the nation. This was notably true of women's groups whose national organizations enlisted the support of state and local branches in organizing nationwide reform campaigns. In 1901, for example, a representative of the National Women's Christian Temperance Union persuaded the Des Moines Women's Club to form a local branch of the National Federation of Consumers' Leagues. The purpose of this branch was to destroy sweat-shops by organizing women to use their power as consumers to force employers to improve the working conditions of women and children. In May 1904, the General Federation of Women's Clubs, in formulating national guidelines for child labor legislation, urged its members to use the child labor law proposed by the National Consumers' League as a model. The Iowa Federation of Women's Clubs had anticipated this recommendation a few months earlier when it sponsored the introduction into the Iowa Senate of a child labor bill that included the principal provisions of the standard law prepared by the National Consumers' League. ${ }^{54}$

The mounting desire of social reformers for uniform state laws led to the organization of the National Child Labor Committee in New York City on April 15, 1904. The committee's purpose was to coordinate and unify the work of national, state, and local organizations in order to achieve as much uniformity as possible in child labor legislation. The committee hoped to persuade the states to agree on minimum standards of child labor legislation, fearing that otherwise interstate competition and rivalry would lead states to adopt the lowest admissible standards or none at all. ${ }^{55}$

Professor Samuel McCune Lindsay of the University of Pennsylvania, secretary of the National Child Labor Committee, moved promptly to organize a national network of state child labor committees. He visited Iowa twice in 1904-1905, addressing the State Federation of Labor and consulting lead-

${ }^{54}$ Iowa State Register, (Des Moines) Oct. 17, 1901; Isaac A. Loos, "Child Labor Legislation in Iowa," Iowa Journal of History and Politics, III (October, 1905), 563-572; Downey, History of Labor Legislation in Iowa, 122-130; Haynes, "Child Labor Legislation in Iowa," 594-595.

${ }^{55}$ Loos, 573-576; Haynes, 583-590, 619-621. 
ers of the various organizations seeking to control child labor. These meetings resulted in the formation of the Iowa Child Labor Committee in the spring of $1905 .{ }^{56}$

Representing mainly the professions and women's organizations, the forty-five members of the Iowa Child Labor Committee included seventeen women, nine professors, the presients of Iowa State College and the University of Iowa, four ministers, three labor leaders, and a sprinkling of doctors, lawyers, and judges. The chairman of the committee's executive committee was Isaac A. Loos, Professor of Political Economy and Sociology at the University of Iowa. E. D. Brigham, the Labor Commissioner, served as secretary of the executive committee. The other five members of the executive committee were Mrs. A. B. Cummins, wife of the governor; Mrs. T. J. Fletcher of Marshalltown, president of the Iowa Federation of Women's Clubs; Mrs. J. C. Hallam of Sioux City, a prominent member of the Iowa Federation of Women's Clubs and the Iowa Equal Suffrage Society; President A. B. Storms of Iowa State College; and President A. L. Urick of the State Federation of Labor. ${ }^{57}$

Launching a statewide campaign to mobilize public support for child labor legislation, the Child Labor Committee sharpened the force and intensity of the social justice movement in Iowa. The movement now possessed all of the elements necessary for successful operation: effective leadership, efficient organization, a well-defined program, growing public support, and national ties. Iowa was ready to make her first major response to the social problems of modern industrialism.

${ }^{56}$ Loos, 576-577, Haynes, 595; Stuckey, The Iowa State Federation of Labor, 41-42.

${ }^{57}$ Loos, 577-579; Iowa Federation of Women's Clubs, Yearbook, 1908-1909 (Cedar Rapids: Huston Printing Company, 1909), 3; Who Was Who in America, I, 1897-1942 (Chicago: A. H. Marquis Company, 1942), 507. 
Copyright of Annals of Iowa is the property of State of Iowa, by \& through the State Historical Society of Iowa and its content may not be copied or emailed to multiple sites or posted to a listserv without the copyright holder's express written permission. However, users may print, download, or email articles for individual use. 